\title{
ENGLISH AND GERMAN STUDIES AT THE JAGIELLONIAN UNIVERSITY BETWEEN THE TWO WORLD WARS: THE IDEAL OF A SCHOLAR AND CHALLENGES OF REALITY*
}

\author{
Tomasz Pudłocki \\ Jagiellonian University in Kraków
}

\begin{abstract}
The author discusses the creation of an ideal of a scholar and its implementation by the circles of English and German specialists at the Jagiellonian University in the interwar period. He considers how the academic activity was combined with "service for the state," increasingly imposed by the reality of the time. The choice of university Germanists and Anglicists from Cracow results from the obvious interconnections between the two groups of scholars and from the fact that by using their example it is easy to see how their specific mission was understood, interpreted and how it translated into everyday business relations. It turns out that academic success did not always guarantee a high position or even remaining in the job. Often, they were determined by various completely different factors.
\end{abstract}

Key words: ideal of a scholar, service for the state, propaganda, Roman Dyboski, Spirydion Wukadinović, Adam Kleczkowski.

All Polish readers know very well now that among the greatest foreign experts in and lovers of our culture and literature are three Americans: Professor G. R. Noyes in California, a brilliant translator of many Polish poets, Professor William J. Rose, an advocate of the philosophical thought of Cieszkowski and ardent and erudite chronicler of Stanisław Konarski's great reforms, finally the youngest of them, Professor Eric Philbrook Kelly, who uses his innate gift of literary invention and exceptional narrative talent to turn the findings of his research on our past into novels. Professor Kelly, having fallen in love with the ruined post-war Poland during his humanitarian service Haller's Army, returned to us later under the aegis of the Kościuszko Foundation to work for a year at the Jagiellonian University, where he wove the atmosphere of the old Cracow into a novel about a bugle player of St Mary's Basilica from the times of King Casimir IV Jagiellon - The Trumpeter of Krakow. ${ }^{1}$

* The author thanks Professor Mirosława Podhajecka and Professor Maria Stinia for inspiring conversations and assistance while writing this text.

1 R. Dyboski, Amerykańska pochwała Wilna, "Czas"Y. 82, 1930, no. 222 of 27 IX, p. 2.

Adres do korespondencji: tomasz.pudlocki@uj.edu.pl 
The quotation with which I started my paper indicates the goals behind Polish learning and culture in the interwar period: to be as recognizable worldwide as possible, regardless of the means of getting the recognition. And even if the author of those words, Roman Dyboski, professor of English philology at the Jagiellonian University strongly overemphasized the significance of the mentioned scholars as the best experts in Polish culture abroad, he meant to emphasize one important premise - here are academics from an empire which the post-war USA was, who not only do research on Poland but also propagate it in various ways. According to Dyboski, the founder of English studies in Cracow, a university professor was therefore not only supposed to perfect his scientific method and publish works but also promote ideas of international cooperation and help to bring people, cultures and states closer togeth$\mathrm{er}^{2}$ For Dyboski it was the Anglosphere that was supposed to counterpoise Germany, France and the Soviet Union and their cultural domination over the contemporary Poland. ${ }^{3}$ The epicenter of those contacts was to be Cracow with its Jagiellonian University. The introductory quotation well shows extent of the contacts and the ambitions Dyboski cherished.

In this article I would like to focus on the creation of the ideal of a scholar and its implementation by the circle of English and German studies specialists from the Jagiellonian University in the interwar period, on how their academic activity was combined with the "service for the state" increasingly imposed by contemporary reality; on how that specific mission was understood and how it translated into everyday business relations. The selection of the group of university professors results from the limited size of this paper and from the fact that there were interconnections among a very small group of academics. Obviously, there were many more people speaking German and/or English in Cracow at the time (including also high school teachers who often conducted their own academic research), yet, limiting the discussion to the circle connected with the Jagiellonian University allows to grasp certain tendencies and to analyze the issue more profoundly.

\section{CULTURAL CONTEXT AND THE CONDITIONS FOR THE DEVELOPMENT OF THE TWO DEPARTMENTS BEFORE 1918}

English was still rarely taught in the Galician educational system. Even compared with the optional French, it was taught in only about a dozen schools, mainly in Lviv and Cracow. The reason was that hardly any teachers spoke it. ${ }^{4}$ If English did

2 Cf.: T. Pudłocki, Idea uniwersytetu wedtug Romana Dyboskiego, "Rocznik Komisji Nauk Pedagogicznych" 2016, vol. 69, pp. 155-173.

3 Idem, Uczeni przeciw ,, milczacej otchtani”. Wspótpraca Moniki M. Gardner i Romana Dyboskiego na rzecz sprawy polskiej w Wielkiej Brytanii, "Zeszyty Naukowe Uniwersytetu Jagiellońskiego. Prace Historyczne" 2014, 141/1, pp. 101-122.

4 Exploring the issue of teaching English in Galician schools goes beyond the scope of this paper, still it is worth investigating, as not many researchers have done it to date - see M. Stinia, Państwowe szkolnictwo gimnazjalne w Krakowie w okresie autonomii galicyjskiej, Kraków 2004, p. 175. 
appear in the teaching offer, it was usually taught by a teacher of French. That was e. g. the case of the VII Gimnazjum in Lviv, where both languages were optional and taught before the war by Józef Dąbrowski, or in I Realschule in Lviv, where English was taught by the excellent French teacher Stanisław Wędkiewicz, later a university professor in Poznań, Cracow and Warsaw. ${ }^{5}$ A rare exception was treating English as an obligatory subject - like in the VIII Gimnazjum in Lviv, where it was taught in selected classes by Fryderyk William Robertson Butler. ${ }^{6}$ One of the few provincial high schools offering English was Archduchess Elisabeth Gimnazjum in Sambir. ${ }^{7}$ It is worth remembering that English instruction in the areas of Eastern Galicia, especially in the regions of Sambir, Drohobych or Boryslav was very practical, due to a large number of emigrants to the USA or Canada, a growing significance of foreign (including English) capital in the mining industry in the Boryslav region, as well as a growing number of sanatorium patients from the West who came e.g. to the nearby Truskavets. ${ }^{8}$

Even the teachers who after the war became employed at universities and started the first English studies departments, had not had an opportunity to actually teach English. Andrzej Tretiak, after the war appointed to the chair of English studies at Warsaw University, had taught German in the III Gimnazjum in Cracow for only half a year (the 1st term of the 1907/1908 and 1909-1910). ${ }^{9}$ Another teacher specializing in English literature (though he taught Polish) was Władysław Tarnawski. He was a teacher first in the I and then III Gimnazjum in Przemyśl; after the war he was appointed to the English studies department in Lviv. It was created specially for him in 1924. ${ }^{10}$ Also Roman Dyboski, the originator of university English studies in Poland, was a German specialist by education. Later he turned into a specialist in English and

5 See Sprawozdanie Dyrekcji Gimnazjum VII we Lwowie za rok szkolny 1912/1913, t. Lwów 1913, p. 26; Sprawozdanie Dyrekcji I Wyższej Szkoty Realnej we Lwowie za rok szkolny 1909/1910, Lwów 1910, p. 42; ibidem for 1912/1913, Lwów 1913, p. 39.

6 Sprawozdanie Dyrekcji Gimnazjum VIII we Lwowie za rok szkolny 1912/1913, Lwów 1913, p. 39.

7 Державний Архів Львівської області [later: DALO], fond 1262, description of Adam Mickiewicz 58 Gimnazjum in Sambir, case 196, k. 32, 39, 45; Sprawozdanie Dyrekcji c.k. Gimnazjum im. Arcyksiężniczki Elżbiety w Samborze za rok 1907, Sambor 1907, p. X, ibidem for 1908, p. X; ibidem for 1910, p. 27.

8 See e.g.: A.F. Frank, Oil Empire: Visions of Prosperity in Austrian Galicia, Cambridge, MALondon 2007.

9 Tretiak was on a leave in the II term of 1908/1909 and the whole year 1910/11; he did not return to high school teaching - see Sprawozdanie dwudzieste szóste dyrekcji c.k. Gimnazjum III w Krakowie za r. szk. 1909, Kraków 1909, p. 48, 50-51, ibidem for 1910, p. 54, ibidem for 1911, pp. 44, 48. See also: P.M. Majewski, Społeczność akademicka 1915-1939 [in:] Dzieje Uniwersytetu Warszawskiego 1915-1945, Warszawa 1945, pp. 51-324 (in particular pp. 81, 103, 303).

10 Cf.: T. Pudłocki, Władysław Tarnawski. Cz. II. Przemyśl, lata przełomu, "Rocznik Przemyski" 2002, vol. 38, issue 1: Literatura i Język, pp. 67-78; idem, Władystaw Tarnawski. Cz. III. Przemyślanin $w$ drodze do katedry uniwersyteckiej, "Rocznik Przemyski" 2004, vol. 40, issue 3: Literatura i Język, pp. 71-92. See also: Ł.T. Sroka, Wydziat Humanistyczny [in:] Academia militans. Uniwersytet Jana Kazimierza we Lwowie, ed. A. Redzik, Kraków 2015, pp. 597-598; M. Chrostek, Zlote lata polonistyki lwowskiej (1919-1939), Rzeszów 2016, pp. 338-342. 
in 1908 became a junior lecturer and then associate professor of English studies at the Jagiellonian University.

Inasmuch as it is easy to count the teachers or speakers of English employed in pre-war high schools, ${ }^{11}$ it was different in the case of teachers of German. The hours of German language instruction in the autonomous Galicia outnumbered those devoted to Polish (or Ukrainian in Ukrainian-language schools). Also the influence of German culture on Polish and Ukrainian ones at that time as well as the significance of German science need not be underestimated. That is why German studies university traditions were not only older but also had much better conditions for development than English studies. Until 1918 German was the language of communication with Vienna and in fact it was hard to find an educated person in Galicia who could not communicate in that language. Because of enormous development of German learning in the 19th century speaking German and publishing in that language were a passport to the world of great science. Many students who wanted to devote themselves to German studies had an opportunity to study not only at Polish universities but above all at Austrian and German institutes of higher education, mainly as government grant-holders. No wonder then that high school teachers were authors of works written in German, from treatises on various subjects (including history of German literature and German linguistics) to poetry, to textbooks, manuals and popular texts. Such people as Adolf Zipper, Kazimierz Missona, Stanisław Gayczak, Józef Flach, Witold Barewicz, Karol Petelenz, Adolf Stylo, Emil Petzold, Roman Hamczykiewicz, Andrzej Aliśkiewicz, Alfred Jahner, Karol Zagajewski, Stanisław Leonhardt, Jakub Rollauer, Juliusz Ippoldt, Samuel Wagmann, Herman Sternbach, Mieczysław Ziemnowicz, Jan Jakóbiec, Zdzisław Żygulski, Adam Kleczkowski, Zygmunt Łempicki, were not only distinguished teachers but also lecturers, associate professors or full university professors whose works in German consolidated the position of German studies in Poland after regaining independence in 1918. ${ }^{12}$

While Galician interests in English studies until 1908 stemmed either from private interests or attending foreign language classes ${ }^{13}$ or comparative linguistic classes, which e.g. in Lviv were conducted by Jan Kasprowicz, in both Galician universities students could take part in regular German studies classes. Before World War I the Jagiellonian University was proud to have Wilhelm Creizenach as a lecturer - one of the most eminent German scholars of his time. When he retired, he was replaced by Spirydion Wukadinović, who ran regular classes until 1932. ${ }^{14}$ One who for many

11 Obviously, the list is longer than those few names I mention, however it requires thorough research which goes beyond the limits of this text.

12 Cf.: Z. Żygulski, Germanistyka [in:] Historia nauki polskiej, ed. B. Suchodolski, vol. 4: 1863-1918, part 3, Wrocław-Warszawa-Kraków 1987, pp. 761-771; M. Cieśla, Dzieje nauk języków obcych w zarysie. Monografia z zakresu historii kultury, Warszawa 1974, pp. 254-258.

${ }_{13}$ At the Lviv University before WWI classes of English were conducted by Paweł Postel and after the war-Charles Irvine (see DALO, fond 26 Uniwersytet Lwowski, op. 15, case 1546 Postel Pawel, case 771 Irvine Charles).

14 M. Stinia, Uniwersytet Jagielloński w latach 1871-1914. Modernizacja procesu nauczania, Kraków 2014, pp. 205-206; U. Perkow ska, Corpus Academicorum Facultatis Philosophiae Universitatis Iagellonicae 1950-1945, Kraków 2007, pp. 50, 427. 
years lectured at the Lviv University was Ryszard Maria Werner, who - like Creizenach in Cracow - had a large group of students. In 1905 the second department of German studies was founded at the Lviv University, assumed by a linguist Józef Schatz from Innsbruck. Werner retired in 1910, Schatz left Lviv in 1912, and then the German studies in Lviv were taken over by Wiktor Dollmayr who continued lecturing until 1938. That second department of German studies after World War I was turned into a department of English studies and assumed by the already mentioned W. Tarnawski. ${ }^{15}$

\section{THE PROBLEMS AND CHALLENGES OF ENGLISH STUDIES AT THE CRACOW UNIVERSITY}

It is worth remembering that the contacts between Poland and Great Britain and its dominions and colonies, or the USA, were not among the priorities of Polish diplomacy. English was still not a popular language, so the students of English were not numerous in the interwar period. ${ }^{16}$ That allowed the only full professor of English at the Jagiellonian University, Roman Dyboski, for a considerable mobility and versatility of initiatives elsewhere in Poland and abroad. ${ }^{17}$

Dyboski had returned to Cracow in January 1922, after seven years of exile in Russia. Because of his war experiences he was excused from conducting lectures in the summer term of 1921/1922; he only ran a two-hour seminar. Soon it turned out that the Cracow scholar's scientific interests had changed - from English literature to Polish culture as well as Poland's social, political, economic and educational problems of the time. The change in his interests resulted from his frequent visits abroad, particularly to Great Britain, and the regular lectures at the School of Slavonic Studies of University of London. ${ }^{18}$

15 Z. Żygulski, op. cit., pp. 764-767. One may not agree with the very superficial characteristics of the German and English studies at the Lviv University provided by L.T. Sroka - see idem, op. cit., pp. 597-598.

16 Władysław Tarnawski wrote on the needs of English studies in Poland in 1929 - see idem, Uwagi o potrzebach anglistyki w Polsce, "Nauka Polska. Jej Potrzeby, Organizacja i Rozwój” 1929, vol. 10, pp. 347-349.

17 For further details on him see: Z. Krajewska, Roman Dyboski (1883-1945), Katowice 1968; M. Laskowska, W. Tarnawski, Dyboski Roman [in:] Polski stownik biograficzny, Kraków 1946, pp. 3-35; Professor Roman Dyboski: Founder of English Studies in Poland. Proceedings of the Commemorative Conference for Roman Dyboski (1883-1945), Kraków, 1-2 June 1995, eds. T. Bela, E. Mańczak-Wohlfeld, Kraków 1997; T. Bela, Roman Dyboski (1883-1945) [in:] Uniwersytet Jagielloński. Złota Księga Wydziału Filologicznego, eds. J. Michalik, W. Walecki, Kraków 2000, pp. 286-288.

18 He conducted classes in London throughout 1922/1923, in the III term of 1923/1924, and in the III term of 1924/1925 - I wrote more about Polish studies in London and Dyboski's role in them in: Ambasadorzy idei. Wkład intelektualistów w promowanie pozytywnego wizerunku Polski w Wielkiej Brytanii w latach 1918-1939, Kraków 2015, pp. 219-262. 
Dyboski published a lot of works in English, both synthetic textbooks (Periods of Polish Literary History, Oxford 1923, 2nd ed. 1928), Modern Polish Literature, Oxford 1924; Outlines of Polish History, Oxford 1925) as well as popular articles in trade journals and daily newspapers. The fact that his works met with a wide response confirmed his choice of career. Still, the analysis of their content revealed that Dyboski presented the readers with Polish history and culture in an accessible way, drawing on other scholars' research and not conducting his own. That was soon brought to the attention of Polish academics, specialists in various fields. Nevertheless, in the light of almost no literature about Poland in the early interwar years Dyboski's "propaganda" work is really significant and worth emphasizing. His publications were not meant to expand the expertise in particular fields but to develop the knowledge on Poland and its cultural heritage in the West. Dyboski's perfect English (a rare thing in Poland at the time), his ability to synthesize, his simple, communicative style, knowledge of English mentality and ability to adjust the content to the readers' expectations (his opponents accused him of deforming facts and sometimes misinterpreting them history-wise), plus his mission to show Polish culture as part of the legacy of Western thought, all contributed to the success of his publications. ${ }^{19}$

The English scholar from Cracow did not publish his works only in English; after returning to Poland he wrote a lot in his native language, too. The scope of his interests was enormous, considering that he also tried to promote Anglo-Saxon culture in Poland. His range of subjects and his ease of writing make it hard for modern researchers to categorize his publications.

Dyboski, nephew of Tadeusz Łopuszański, a long-time undersecretary of state in the Ministry of Religious Denominations and Public Education, was able to find a way to the new authorities also after 1926. His connections with the circles of Polish diplomacy and his support for Piłsudski's rule (despite some criticism) did not go unnoticed. Dyboski repeatedly spoke as an expert on British and American matters, the more so because in the late 1920s his interests started to revolve around the US culture. He also represented Polish scholars at many international conventions, especially of educational nature ${ }^{20}$; he collaborated with the "Poland" monthly published by The American Polish Chamber of Commerce and Industry in the United States. ${ }^{21}$ He was also successful there: he became a representative of the New York-based Kościuszko Foundation and in the years 1928-1929 he visited the USA as a visiting

19 I write about it in detail in: Ambasadorzy idei..., pp. 231-245, 263-317.

20 The Archive of New Files, fond 503 Ambasada RP w Londynie (The Embassy of the Republic of Poland in London), sign. 813 Wymiana profesorów między Polską a Wielką Brytanią (Exchange of professors between Poland and Great Britain)..., k. 107, 111; The Archives of the Jagiellonian University in Krakow [later: AUJ], fond The Faculty of Philosophy [later: WF] II 534 University celebrations and anniversaries; T. Pudłocki, Ambasadorzy idei..., pp. 296-298.

21 He published there among others: The Peasant in Modern Poland, "Poland" 1923, no. 8, pp. 89-93, 124; Literature and National Life in Poland, "Poland" 1924, no. 11, pp. 273-276, 324-327, 1924, no. 12, pp. 351-354, 391-392; The Peasant in Polish Literature, "Poland" 1925, no. 4, pp. 201-204, 254-260; American and Polish Democracy, "Poland" 1926, no. 2, pp. 69-70, 108-114; Educational Progress in the New Poland, "Poland" 1928, no. 11, pp. 691-698, 762. Based on Dyboski's memoirs and Conrad's letters to him Z.S. published the article: Conradiana, "Poland" 1926, no. 8, pp. 469-471, 512. 
scholar, delivering lectures at many prestigious universities on the East Coast. Dyboski also lectured during one term at Chicago University; in the fall of 1929 he arrived with the Polish delegation to attend the celebrations of the 125th anniversary of the death of Kazimierz Pułaski and he met with American President Herbert Hoover. ${ }^{22}$ In the 1930s he would give opinions on candidates for the Kościuszko Foundation grants, which largely contributed to sending Professor Oskar Halecki from Warsaw to the USA in the academic year 1938/1939. ${ }^{23}$

Dyboski's ambitions to become head of the ministry of education were no secret to his colleagues. On the other hand, they noticed a considerable change in the scholar's behavior. While until the First World War he had been known as author of great publications and accurate research, between the wars he mainly wrote popular texts. It is hard to blame him, as Dyboski had become a hostage of his own success. Well-read, eloquent, fluent in a few languages, extremely intelligent and able to talk on various subjects, with plenty of commissions for texts and books, he could hardly find any time for thorough academic research. That is why the English studies in Cracow at the time mainly promoted Anglo-Saxon culture in Poland and Poland in the English-speaking world rather than being a center of accurate academic research. And although Dyboski never became a minister, his international contacts were appreciated by his colleagues: he was responsible for the Jagiellonian University relations with American universities ${ }^{24}$ and was chosen Dean of the Faculty of Philosophy of the Jagiellonian University for the academic year 1930/1931. Earlier, as curator of the Brotherly Help he would obtain considerable funds for that organization but as dean he managed to get significant funding for building a new student hostel, which was not easy during the Great Crisis. It would not have been possible without the involvement of Steven Mizwa, executive director of the Kościuszko Foundation who Dyboski was friends with and who visited Cracow in 1930 and 1939, entertained by the local academic community. ${ }^{25}$

Dyboski's frequent trips abroad and his involvement in many ventures Polandwide (which are only briefly mentioned here) were not always welcome by university authorities. On the one hand they raised the prestige of the department and the

22 Cf.: The Kosciuszko Foundation Archives [later: KFA], S. Mizwa's Archives, KF VI.42 Dyboski Roman, prof. Lectures in USA; S. Mizwa, Kosciuszko Foundation News, "Poland" 1928, no. 11, p. 764, no. 12, pp. 899-900; The Archive of New Files in Warsaw, fond 490 Ambasada RP w Waszyngtonie (The Embassy of the Republic in Poland in Washington), sign. 1403-1410 (obchody Pułaskiego / Pułaski celebrations, 1928-1931).

${ }_{23}$ Cf.: KFA, S. Mizwa's Archives, KF VI.40 Dyboski Roman; KF VI.41 Roman Dyboski. Publicity. 1928-1933; KF XI.1 Correspondence. Oskar Halecki, 1937-1939. See also: T. Pudłocki, Pierwsze stypendystki Fundacji Kościuszkowskiej z Polski w Stanach Zjednoczonych Ameryki (1925-1939) [in:] Człowiek - społeczeństwo - źródto. Studia ofiarowane Profesor Jadwidze Hoff, eds. Sz. Kozak, D. Opaliński, J. Polaczek, Sz. Wieczorek, W. Zawitkowska, Rzeszów 2014, pp. 119-133.

24 AUJ, WF II 529 Programy studiów uczelni zagranicznych i kursów organizowanych przez UJ dla cudzoziemców 1894-1939 (Programs of studies at foreign universities and courses organized by the Jagiellonian University for foreigners 1894-1939), WF II 530 Zawiadomienia o wycieczkach krajowych i zagranicznych z lat 1928-1939 (Announcements on trips in Poland and abroad 1928-1939).

25 KFA, S. Mizwa's Archives, Photo Collection; "Nowy Świat” Y. 33, 1930, no. 261 of 18 IX, p. 1. 
university but on the other hand they put the authorities in a difficult situation: even though the number of English students was not large, every time it was necessary to find a replacement for Dyboski. Usually it was Michał Henryk Dziewicki, who worked as a university teacher in the years 1896-1928. Dyboski valued him as his former lecturer and colleague, the more so as Dziewicki's translation of both scientific literature and fiction had brought him wide recognition. It was particularly the translation of W. S. Reymont's Chtopi that received best reviews. ${ }^{26}$ E.P. Kelly wrote about him as follows:

Dziewicki is one of the best known and most loved figures in the streets of Cracow. Although he is over seventy years old, he teaches more than eight hours a day, and has besides private pupils, which bring his teaching hours closer to twelve a day. [...] yet this old man marches ahead with marked vitality and entusiasm. He is a born teacher and loves teaching. His labors are prodigious, and the results are quite apparent, for he has established a real English cult in Cracow and in other cities. ${ }^{27}$

The quotation proves that Dziewicki was a devoted teacher. However, despite his willingness and generally acknowledged erudition, due to both his age and the fact that he focused on translations and not on academic research, he could not substitute for Dyboski in the long run. Also Eric P. Kelly helped with the classes - a lecturer of English literature in Dartmouth College in Hannover, who worked at the Jagiellonian University in the academic year $1925 / 1926$ and in $1927 .{ }^{28}$ Kelly proved to be a great enthusiast of Polish culture and of Dyboski himself. Although he did not really get ahead in the academic world, he achieved renown as a successful author of children's books based on Polish motifs. ${ }^{29}$ He sometimes published texts in the "Poland" monthly. ${ }^{30}$ After Dziewicki's death the lecturer became Jan Stanisławski, who also occasionally ran Dyboski's classes. ${ }^{31}$ In the 1930s Dyboski went away less and got

26 See E.P. Kelly, The Peasants (Winter of the Nobel Prize). Part I. Autumn (The Peasants, by Ladislas Reymont, transl. by M.H. Dziewicki, Alfred A. Knopf \& Co., Inc, New York), "Poland" 1924, pp. 345-346, 384-386; idem, Winter Comes, "Poland" 1925, no. 3, pp. 158, 182-184; idem, The Peasants - Vol. III - Spring, "Poland" 1925 no. 6, pp. 349, 368-369; idem, The Last Volume of "The Peasants", "Poland" 1925, no. 7, pp. 412, 432-434.

27 E.P. Kelly, A Venerable Polish Scholar, "Poland" 1926, no. 10, p. 627-628.

28 American Soil is Added to Kosciuszko’s Mound, "Poland" 1926, no. 10, p. 604.

29 The Trumpeter of Krakow was declared Children's Book of the Year in the USA in 1928 and was repeatedly published. It made Kelly a famous author for Young readers. After his return to Poland and archive work in Lviv and Vilnius he wrote novels The Blacksmith of Vilno. A Tale of Poland in the Year 1832 (1930), The Golden Star of Halich: A Tale of the Red Land in 1362 (1931). Later he published among others: The Land of the Polish People (1943), From Star to Star: A Story of Krakow in 1493 (1942) and The Hand in the Picture: A Story of Poland (1947). See T. Pudłocki, Ambasadorzy idei..., p. 315 .

30 See e.g.: E.P. Kelly, The Heart of Democracy, "Poland" 1924, pp. 135-140, 188; A Wonderful Tale of Old Poland for Children and "Grown-Ups" Alike, "Poland" 1924, no. 7, pp. 29-36, 50; Another Tale of Old Poland for Children, "Poland" 1924, no. 9, pp. 161-164, 182-187; A History in Song, "Poland" 1924, no. 12, p. 335-340; The Great Polish Secret, "Poland" 1925, no. 7, pp. 414, 434-436; A Venerable Polish Scholar, "Poland" 1926, no. 10, pp. 627-628.

31 Cf.: M. Podhajecka, A History of Polish-English/English-Polish Bilingual Lexicography (1788-1947), Opole 2016, pp. 337-340; U. Perkowska, op. cit., p. 349. 
more engaged in the university work. ${ }^{32}$ He employed junior lecturers: Rudolf Mahr (1929/1930-1932/1932), Maria Patkaniowska (1932/1933-1935/1936), Krystyna Michalik (1936/1937-1938/1939). None of them got ahead in their university careers despite promising texts published before 1939 and despite the fact that Dyboski arranged for them all visits to English-speaking countries and supported their attempts, obtaining funds for them. ${ }^{33}$

\section{SPIRYDION WUKADINOVIĆ AND THE GERMAN STUDIES AT THE CRACOW UNIVERSITY UNTIL 1932}

In the Second Republic of Poland German culture continued to influence social and cultural life of the Polish citizens, by no means only the German, Jewish or Ukrainian minorities. Despite the tense political situation and the constant propaganda struggle, the German influence in film, music, art, science and literature was enormous - and also the achievements of Polish culture, though often downplayed by some German politicians, were appreciated by professionals from the Weimar Republic. A lot of outstanding Polish poets and writers, particularly Leopold Staff, would familiarize Polish readers with the works of German authors and the number of translations from German was second only to translations from English, exceeding the works of the French and Russians. German literature was also easily imported and read in the original. As Bogusław Drewniak wrote: "In 1935 the share of Germanlanguage publications in the whole import of foreign publications reached $85 \%$ ". ${ }^{34}$ Therefore, if the Poles at the time read foreign literature in the original, it was first of all in German. Polish press wrote frequently and very positively about the visits of German writers and scholars, especially as not all of them were at the service of state propaganda or connected with national socialism. ${ }^{35}$

32 The subject matter of his lectures was discussed by J. Dybiec - see idem, Uniwersytet Jagielloński 1918-1939, Kraków 2000, pp. 247-248 and other information on Dyboski's functioning in the structures of the Jagiellonian University according to index.

33 The preserved lists of the publications of the English studies staff from selected 1930s include academic interests of the university Anglicists. However, what dominates there is popular texts, often published in the Cracow "Czas" or short monographs. Dyboski, although a prolific author, at that time did not take up any original ideas. - The Archives of the Polish Academy of Sciences (PAN) and the Polish Academy of Learning (PAU) in Cracow, Roman Dyboski legacy, sign. K III-90 (in Progress). See also: AUJ, WF II 88 Zasiłki rządowe na studia w kraju i zagranicą, ulgowe paszporty 1918-1939 (Government subsidies for studying in Poland and abroad, preferential passports 1918-1939); U. Perkow ska, op. cit., pp. 225, 239, 280.

34 B. Drewniak, Polsko-niemieckie zbliżenia w kręgu kultury 1919-1939, Gdańsk 2005, p. 95. Cf.: J. Wnęk, Polskie przektady literatury zagranicznej 1918-1939, Kraków 2006.

35 Cf. B. Drewniak, op. cit., pp. 64-173. On the problems of German studies in Poland in 1929 see Zygmunt Łempicki - idem, Filologia germańska, jej zadania i potrzeby w Polsce, "Nauka Polska. Jej Potrzeby, Organizacja i Rozwój” 1929, vol. 10, pp. 336-346. 
The German studies at the Jagiellonian University were for many years headed by Spirydion Wukadinović. As Michał Cieśla had proved years before, he was an Austrian German whose family was of Serbian origin. ${ }^{36}$ His mother was Polish. ${ }^{37}$ Wukadinović's work has been repeatedly discussed and it is hard to contribute anything new to the subject, particularly as the scholar devoted himself largely - and successfully - to academic research and literature. His scholarly activity was an important part of Germanist university traditions and in a way, thanks to his extensive contacts in the German-speaking world, contributed to their consolidation, especially as he published mainly abroad. ${ }^{38}$

While he did not engage in the work of local academic institutions (regardless of their range), he was appreciated in the Polish circles (not only scientific ones) mostly as the translator of Polish literature into German. Already as a pensioner, he translated a few songs from Mickiewicz's Pan Tadeusz (published in "Pologne Literaire" in 1935) and selected works by Kochanowski (Threnodium und andere Gedichte, Mikołów 1934). Although he complained about the lack of contacts and the indifference with which his translation of Odprawa postów greckich (Die Abfertigung der griechischen Gesandten, Poznań 1929) ${ }^{39}$ met on the part of Polish authorities, his work was mentioned even by Polish press in New York:

[...] The translator is Professor Wukadinowicz, a lecturer of German literature at the Jagiellonian University, well known in the academic literature of his subject mainly through his studies on German Romantic writing. Professor Wukadinowicz is also a writer himself; an author of a play about Goethe's life, successfully performed on German stages. [...] In his translation of Odprawa... Prof. Wukadinowicz follows closely the rhythm of the original. A book so beautifully published and so carefully prepared may render Kochanowski famous in the whole German-language world. In the post-war world, still disturbed by outbursts of hatred, Professor Wukadinowicz's work is a beautiful example of an effort of a spirit on the height of art. ${ }^{40}$

Stanisław Zabierowski wrote in the Warsaw "Ruch Literacki" about the "perfect translation" of Odprawa postów greckich, emphasizing that Wukadinović's work "is at the same time the major work among the existing German-language translations of and studies on Kochanowski." ${ }^{41}$ In the same issue of "Ruch" Józef Birkenmajer,

36 M. Cieśla, Spirydion Wukadinović profesor germanistyki na Uniwersytecie Jagiellońskim (1870-1938). Wspomnienie o nim [in:] Z dziejów germanistyki historycznoliterackiej w Polsce. Studia i materiały, ed. K.A. Kuczyński, Łódź 1991, p. 93.

37 AUJ, WF II 157 Katedra i Seminarium Filologii Germańskiej 1851-1939 (The Chair and Seminar of German Studies 1851-1939).

38 M. Cieśla, Spirydion Wukadinović..., pp. 98-104; O. Dobijanka-Witczakowa, Historia katedry germanistyki w Uniwersytecie Jagiellońskim [in:] Wydziat Filologiczny Uniwersytetu Jagiellońskiego. Historia katedr, eds. W. Taszy cki, A. Zaręba, Kraków 1964, pp. 357-358; A. Kleczkow ski, Germanistyka, anglistyka i skandynawistyka w Polsce, Kraków 1948, p. 25; M. Kłańska, Spiridion Wukadinović (1870-1938) [in:] Uniwersytet Jagielloński..., pp. 216-222; K.A. Kuczyński, Zygmunt Łempicki i polska germanistyka okresu międzywojennego [in:] Z dziejów germanistyki historycznoliterackiej w Polsce. Studia i materiały, ed. K.A. Kuczyński, Łódź 1991, p. 29.

39 B. Drewniak, op. cit., pp. 119-121.

40 "Nowy Świat" Y. 33, 1930, no. 40 of 9 II, p. 10.

41 S. Zabierowski, Kochanowski $w$ wersji niemieckiej, "Ruch Literacki" Y. 5, 1930, no. 6, pp. $176-178$. 
despite noticing a few minor errors in the text, almost built a monument to the translator with his review. ${ }^{42}$ A lot of attention was devoted to Wukadinović's work by the Czech daily "Prager Presse" in the article Germanoslavica. Jan Kochanowski in deutschem Gewande. What was praised was the precision but also the literary aspect of the translation. The anonymous reviewer ended his text as follows:

Wukidanović rechnet auf die in Polen lebenden Deutschen und erhofft, dass sein Versucht vielleicht auch über die Grenzen des polnischen Staates hinaus als Kleiner Beitrag zur Annäherung zweier Kulturvölker Beachtung finden werde. De guten Willen und der schönen Leistung wäre dieser Erflog zu wünchen. ${ }^{43}$

There is another aspect of Wukadinović's activity that is worth emphasizing - his devotion to teaching. Although the scholar did not agree to open a second department of German studies in Cracow (like in Lviv), ${ }^{44}$ during his university work he educated a number of teachers of German (over 100 people) and about 30 doctors. ${ }^{45}$ No wonder then that on the 60th anniversary of the scholar's birth the New York "Nowy Świat" remembered him and his academic and translation achievements, writing: "As a teacher he wins the students over with his friendly attitude and as a professor he stands up to academic requirements, offering good advice to young people who want to study German philology." ${ }^{46}$ Wukadinović appears to have been an ideal scholar, distinguished by his academic professionalism and outstanding achievements, and at the same time approachable as an educator of new generations. He also served the idea of promoting Polish culture through his first-rate translations. The analysis of both articles from Polish press abroad allows to draw a conclusion that a scholar - in the eyes of public opinion - was expected to serve the Polish state and society, regardless of his specialization. That in the case of Wukadinović it was not just empty praise we can read e.g. in the memoirs of Michał Cieśla, who confirms Wukadinović's enormous involvement in conducting his classes and working with students. He describes him as a serious, cheerful man, never moody, generally respected and liked by students because of his unusual openness to their problems. ${ }^{47}$ The minutes of meetings and the chronicle of the Association of German Scholars confirm Cieśla's words. ${ }^{48}$

In teaching ${ }^{49}$ Wukadinović was helped out by a junior lecturer of German, high school teacher and outstanding scholar and educator Juliusz Ippoldt (employed at the

42 J. Birkenmajer, rev.: Kochanowski Jan, Die Abfertigung der griechischten Gesandten. Übersetz und mit Einleitung und Anmerkungen versehen von Sp. Wukadinović. Mit zwei Anhägen, Poznań b.r. [1929] p. 80, "Ruch Literacki"Y. 5, 1930, no. 6, pp. 183-184.

43 "Prager Presse" Y. 9, 1929, no. 347 of 22 XII, pp. 10-11.

44 On that issue a debate took place in which the following Germanists took part on 13 II 1922: K. Dziewoński, S. Wukadinović, I. Chrzanowski, R. Dyboski, J. Rozwadowski, S. Wędkiewicz and K. Nitsch, and the main subject of the debate explained his stand in writing - AUJ, WF II 157 Katedra i Seminarium Filologii Germańskiej 1851-1939 (The Chair and Seminar of the German Studies).

45 M. Cieśla, Spirydion Wukadinović..., p. 97.

46 "Nowy Świat" Y. 33, 1930, no. 138 of 18 V, p. 6.

47 M. Cieśla, Spirydion Wukadinović..., p. 97.

48 AUJ, O 74/I Koło Germanistów (The Association of Germanists).

49 The subject matter of his lectures was discussed by J. Dybiec - see idem, op. cit., pp. 246-247. 
Jagiellonian University in the years 1910-1929), who also gave lectures on descriptive grammar of modern German. ${ }^{50}$ Later, from 1930, the classes in historical grammar were taken over by a junior lecturer, doctor Bronisława Rosenthalowa. ${ }^{51}$ In the years 1927/1928-1928/1929 a deputy junior lecturer was also Leon Müller. Doctor Marta Unger ran classes in the years 1929/1930-1933/1934 after Juliusz Ippoldt, and in the last two years of her work - freelance lectures and seminars in literature. However, all that was of little help with such a large number of students and constant problems with accommodation Wukanović had to face in the $1920 \mathrm{~s} .{ }^{52} \mathrm{He}$ did not go abroad as often as Dyboski, though, and if he did, it was mostly to Germany, Austria and Czechoslovakia. His journeys did not disturb the work at the university, as it was often the case with Dyboski. ${ }^{53}$

\section{THE ARGUMENT BETWEEN SPIRYDION WUKADINOVIĆ AND ADAM KLECZKOWSKI}

Whereas Wukadinović's scholarly and translation achievements as well as his involvement in teaching and students' matters were unquestionable, his many years' seclusion from Polish academic institutions and isolation from his colleagues could be a nuisance. The only professor whom he valued and favored was Dyboski - the most frequent internal reviewer of students' diploma theses in the German studies department; however, apart from him Wukadinović maintained hardly any relations with other professors. ${ }^{54}$ It was at the same time that the academic achievements and extensive local social contacts of Adam Kleczkowski (graduate of the Jagiellonian University, then professor in Poznań), who was trying to return to Cracow, made some Cracow professors think of some reshuffling at the Department of Philosophy. Of considerable significance was also the constant Polish-German dispute and desire (against the regulations from the Austrian times) to staff the German studies department with Polish academics of suitable qualifications and achievements. ${ }^{55}$

Although for many years there had been no problems regarding Wukadinović's nationality, now suddenly a scandal broke out around one of his speeches. During a convention in Weimar organized in March 1932 by the Goethe Society Wukadinović delivered a famous speech titled "Goethe und Polen," analyzing anti-

${ }^{50}$ On Ippoldt and his work see e.g.: O. Dobijanka-Witczakowa, op. cit., pp. 355-356; A. Kleczkowski, Germanistyka..., p. 24.

${ }_{51}$ Her work is discussed e.g. in: A. Kleczkowski, Germanistyka..., p. 31; O. Dobijanka-Witczakowa, op. cit., p. 359.

52 AUJ, WF II 157 Katedra i Seminarium Filologii Germańskiej 1851-1939 (The Chair and Seminar of the German Studies); WF II 192 Lektorat języka niemieckiego w latach 1851-1938 (German language classes in the years 1851-1938); U. Perkowska, op. cit., pp. 255, 311, 399-400.

53 AUJ, S II 619 Wukadinović Spirydion; M. Cieśla, Spirydion Wukadinović..., p. 98.

${ }_{54}$ M. Cieśla, Spirydion Wukadinović..., p. 98.

55 K.A. Kuczyński, Zygmunt Łempicki i polska germanistyka..., p. 27. 
Polish (real or alleged) motifs in Goethe's texts, especially in an unpublished but attributed to him work Vorschlag zur Einfürung der deutschen Sprache in Polen of 1794. Wukadinović's paper was highly valued by foreign scholars, especially that the author had already presented well-known results of his research. What was more, President Paul von Hindenburg awarded Wukadinović with a medal for his work. ${ }^{56}$ The event instantly rebounded on the Cracow scholar. Kleczkowski expressed his objection and declared to Professor Julius Petersen, the chairman of the Goethe Society, that he had no intention of giving his own presentation after a speech so offensive to Poland delivered by a representative of the Jagiellonian University. ${ }^{57}$ Petersen was not only an eminent researcher of Goethe's work but also one of the main advocates of national socialism in German science, which could be taken advantage of in the period of tense Polish-German relations..$^{58}$ It is worth emphasizing that March 1932 saw an aggressive pre-election campaign in Germany, during which revisionist parties made various accusations against Poland. ${ }^{59}$ Wukadinović involuntarily became a victim of those actions.

Both Kleczkowski and the employees of the Polish embassy in Berlin wrongly interpreted and misunderstood the lecture, perceiving it as behavior unworthy of a professor of a Polish university. So far the role of Kleczkowski in the whole affair has been ignored in Polish historiography, although it seems to have been of no small consequence. ${ }^{60}$ The witch-hunt aimed at Wukadinović was not only of political but also of cultural nature. Poland was celebrating the 100th anniversary of Goethe's birth on account of the poet's popularity, and the question of Wukadinović's lecture cast an unnecessary shadow over it. ${ }^{61}$ Before the scholar returned from the convention, the Polish embassy in Berlin ${ }^{62}$ intervened about his presentation in the Ministry of Religious Denominations and Public Education. Wukadinović was suspended in

56 M. Cieśla, Spirydion Wukadinović..., p. 99.

57 The Library of the Polish Academy of Learning in Cracow, the Manuscripts Catalogue [later: BPAU], sign. 6468 Materiały z lat 1926-1932 dotyczące sporu Spirydiona Wukadinovicia z Adamem Kleczkowskim (Materials of 1926-1932 on the argument between Spirydion Wukadinović and Adam Kleczkowski), c. 8.

58 Cf.: Petersen, Julius [in:] Internationales Germanistenlexikon 1800-1950, ed. Ch. König de Gruyter, Berlin 2003, pp. 1385-1388.

59 "Czas"Y. 84, 1932, no. 73 of 31 III, p. 1.

60 M. Kłańska, Spiridion Wukadinović (1870-1938) [in:] Germanistik in Polen. Zur Fachgeschichte einer literaturwissenschaftlichen Auslandsgermanistik - 18 Porträts, eds. W. Kunicki, M. Zybura, Osnabrück 2011, pp. 22-23.

${ }_{61}$ See e.g. the Easter issue of "Czas" (1932, no. 71 of 26 III) and the articles: Rev. K. Michalski, Faust Geothego. Glossa wielkanocna (p. 2; part II - no. 76 of 3 IV, p. 1), J. Twardowski, Stosunek Goethego do narodu polskiego (pp. 2-3) - Twardowski referred to Wukadinović's work Goethe und Polska of 1930, appraising it as valuable and aptly addressing the myths attributed to Goethe. See also: "Czas" 1932, no. 48 of 28 II, p. 2, no. 66 of 20 III, p. 3, or a beautiful article by Wukadinović's student Doctor Zofia Ciechanowska titled Faust w Polsce (no. 76 of 3 IV, p. 4) - she was an outstanding researcher on Goethe's work (see: O. Dobijanka-Witc zakowa, op. cit., pp. 359-360).

${ }_{62}$ M. Cieśla accuses Józef Lipski of acting against Wukadinović, but the ambassador at the time was Alfred Wysocki, who does not mention the action against the Cracow professor in his memoirs - A. Wysocki, Tajemnice dyplomatycznego sejfu, $2^{\text {nd }}$ edition, Warsaw 1979. 
his duties and it was suggested he should ask the university to be pensioned off. Eventually, abandoned Wukadinović submitted the expected letter on 26 April $1932 .{ }^{63}$ Professor Kazimierz Nitsch apparently said that the department would have dismissed him anyway, as the academic had become extremely difficult to work with and his attitude towards his university duties, especially teaching, at the time, left a lot to be desired. ${ }^{64}$ This opinion was unjust; even if the reports from the meetings of the Faculty Council confirmed that Wukadinović attended them rarely, he fulfilled his teaching duties without fault. ${ }^{65}$

It was only then that Kleczkowski could be brought to Cracow. A great advocate of that move was Dyboski, whom - paradoxically - Wukadinović valued highest among all his university colleagues. In the letter to Kleczkowski of 27 May 1932 starting with the words "Dear Adam" (which indicated familiar terms), Dyboski informed his colleague of the progress of his appointment. Dyboski had presented Kleczkowski and his achievements before the Faculty Council. All the people present voted to entrust him with taking over the German studies department. ${ }^{66}$

Resolving the problem in that way and the unfairness of the fellow workers made Wukadinović bitter and he decided to get his feelings off his chest. In the 189 issue of the Bytom-based "Ostdeutsche Morgenpost" of 10 July 1932 Wukadinović accused Kleczkowski of plagiarism and went on to add that most works of that Germanist from Poznań were plagiarisms. Kleczkowski learned about that from Dyboski, whom Wukadinović, apparently trustful, showed the article. Dyboski showed it among others to Rev. Rector Konstanty Michalski and Dean Władysław Szafer, who had already obtained the newspaper note from an unknown source. ${ }^{67}$ A copy of the abusive article Dyboski sent to Kleczkowski. He also agreed to represent him before a court of honor. On 31 July 1932 Dyboski wrote to his friend that the rector felt obliged to send explanations to university circles in Stockholm and Budapest; he was also going to write to Wukadinović to warn him against carrying out such campaigns, using bias and inaccurately presented facts. ${ }^{68}$ Dyboski's clear stand on that case and his unclear

${ }_{63}$ M. Cieśla, Spirydion Wukadinović..., p. 99.

64 BPAU, sign. 6468 Materiały z lat 1926-1932 dotyczące sporu Spirydiona Wukadinovicia z Adamem Kleczkowskim (Materials of the years1926-1932 on the argument between Spirydion Wukadinović and Adam Kleczkowski), c. 8; AUJ, S II 619 Kleczkowski Adam.

65 AUJ, WF II 49 Protokoły Wydziału Filozoficznego za lata 1925-1939 (The minutes of the Faculty of Philosophy for the years 1925-1939); O 74/I Koło Germanistów (The Association of Germanists); M. Cieśla, Spirydion Wukadinović..., pp. 95-97.

66 BPAU, sign. 6463 Korespondencja Adama Kleczkowskiego z lat 1906-1949 (The correspondence of Adam Kleczkowski of the years 1906-1949), c. 33. See also the minutes from the meeting of the Faculty Council of 27 V 1932 - AUJ, WF II 49 Protokoły Wydziału Filozoficznego za lata 1925-1939 (The minutes of the Faculty of Philosophy for the years 1925-1939), c. 215.

${ }_{67}$ AUJ, S II 619 Wukadinović Spirydion.

68 BPAU, sign. 6463 Korespondencja Adama Kleczkowskiego z lat 1906-1949 (Adam Kleczkowski's correspondence of 1906-1949), c. 35-36. On 9 VIII 1932 Rector Michalski wrote: "Dear Professor, 'Ostdeutsche Morgenpost' has sent me a note from one of the issues, which I am enclosing here. Having investigated the matter in the Faculty of Philosophy, I was informed that you do not want to sit on the committee which is to deal with the successor at the German studies department. I am sorry that the matter is still making headlines; if this continued, the Faculty would examine the problem in detail ab ovo. 
role in spreading the word of Wukadinović's accusations against Kleczkowski understandably led to breaking off the social contacts between them. Another representative of Kleczkowski's interests was to be a Cracow linguist, Kazimierz Nitsch. However, as he had already broken off any contact with Wukadinović, he asked Dyboski to appoint someone else to demand explanations on his behalf. Professor Tadeusz Jan Kowalski, an Orientalist and Turkologist, agreed to take on that role. However, the trial did not take place. On 27 September 1932 Dyboski explained that the Cracow professors "did not want an international scandal, as it was not possible to come to an agreement with Wukadinović." ${ }^{69}$ As Kleczkowski explained in a letter to the Disciplinary Committee of the Professors of Poznan University:

Both my deputies, professors Dyboski and Kowalski, after communicating with their university authorities, decided that for the good of both Polish universities it was best not to raise the issue, as Professor Wukadinović might also accuse them of partiality, as well as all the professors at the Faculty of Philosophy of the Jagiellonian University, and demand to have Germans from the Reich as judges, in order to give the matter a wide publicity abroad. ${ }^{70}$

In the end, on 30 September 1932 Wukadinović was officially pensioned off, having complained to the Rector that he had been deprived without his knowledge or will of the right to sit on the committee meant to appoint his successor. ${ }^{71}$ Indeed, the Faculty Council which met on 29 April 1932 chose committee members, among whom were professors: R. Dyboski, W. Folkierski, T. Lehr-Spławiński, K. Nitsch, S. Wędkiewicz and H. Willman-Grabowska. Among the candidates to assume the chair were: A. Kleczkowski from Poznań, Zdzisław Łempicki from Warsaw, Zdzisław Żygulski from Lviv, Konrad Bittner from Prague and Hans Halm from Vienna, but all along the favorite had been Kleczkowski - the local graduate. ${ }^{72}$

In the light of Wukadinović's accusations, at the turn of October and November 1932 both universities, in Poznań and in Cracow, organized a joint committee, during whose debate Kleczkowski was questioned. Evidence was also given by Dyboski and Nitsch, who spoke positively about their colleague's reliability and accuracy. Meanwhile another anonymous abusive article was published in "Ostdeutschen Morgenpost," in issue 303 of 1 November 1932, in which the Germanist was accused of poor knowledge of German and plagiarizing W. Creizenach. ${ }^{73}$ Eventually Kleczkowski was cleared of all accusations. Wukadinović, now in conflict with the circles of university philologists, remained in Cracow, where he died on 25 May 1938. Thanking

I am certain that you would like all this to end and to be left alone, as you have already declared. Yours faithfully" (AUJ, S II 619 Wukadinović Spirydion).

69 BPAU, sign. 6463 Korespondencja Adama Kleczkowskiego z lat 1906-1949 (Adam Kleczkowski's correspondence of 1906-1949), c. 40.

70 BPAU, sign. 6468 Materiały z lat 1926-1932 dotyczące sporu Spirydiona Wukadinovicia z Adamem Kleczkowskim (Materials of 1926-1932 on the argument between Spirydion Wukadinović and Adam Kleczkowski), c. 9.

71 AUJ, S II 619 Wukadinović Spirydion.

72 AUJ, S II 619 Kleczkowski Adam.

73 BPAU, sign. 6468 Materiały z lat 1926-1932 dotyczące sporu Spirydiona Wukadinovicia z Adamem Kleczkowskim (Materials of 1926-1932 on the argument between Spirydion Wukadinović and Adam Kleczkowski), c. 8. See also: M. Kłańska, Spiridion Wukadinović (1870-1938)..., pp. 22-25. 
Dyboski for his letter and support in the argument with Wukadinović, on 23 December 1932 Kleczkowski tried to sum up the whole situation: "In our life we tend to be too lenient and that is why people can trade in knowledge and say and write whatever they please." 74 These words partly refer to himself: on the basis of preserved documents one cannot but conclude that Kleczkowski's role in the argument with Wukadinović was not entirely fair and the price he had paid for his nomination was the scandal. In later years Kleczkowski would prove he sometimes behaved unfairly and not entirely ethically. ${ }^{75}$

\section{THE STABILITY OF THE GERMAN STUDIES UNDER ADAM KLECZKOWSKI}

The connections between the German and English studies at the Jagiellonian University, particularly between the professors from both departments, were very strong. That resulted largely from the fact that Dyboski had remained in very good social contact both with Wukadinović and Kleczkowski, which facilitated their collaboration. However the heads of departments supported each other also on the university level (e. g. appointing Dyboski as internal reviewer of students' theses in the German studies department). Dyboski had been a member of the department committee for appointing a professor of German studies, which eventually selected Wukadinović even before the outbreak of World War I. ${ }^{76} \mathrm{He}$ also temporarily managed one part of the German studies seminar before Wukadinović came to Cracow. ${ }^{77}$ Well, he was himself a great Germanist, who published his works on English studies in German and reflections on German literature were quite significant in his work. When Wukadinović was on a scientific leave in the third term of the academic year 1928/1929, Dyboski (alongside Ippoldt) conducted one class of German studies a week. ${ }^{78}$ When Dyboski lectured in the USA in the I and II terms of the academic year 1928/1929, Wukadinović headed the English studies department and conducted a seminar there. ${ }^{79}$ And after the "pensioning off" of Wukadinović, Dyboski took over

74 BPAU, sign. 6491 Różne notatki Adama Kleczkowskiego i kopie listów do różnych z lat 19191949 (Adam Kleczkowski’s various notes and copies of letters of 1919-1949), c. 188-190.

75 Such was the case before the war during the lectures at the Catholic University of Lublin, or after the death of R. Dyboski and arresting Prof. W. Tarnawski, when Kleczkowski became the head of the English studies department. See: KFA, J. MacCracken Files, the letter of James MacCracken to Steven Mizwa of 1 VII 1947; T. Pudłocki, James MacCracken as a Lecturer at the Jagiellonian University (1946-1948) [in print].

${ }^{76}$ AUJ, WF II 157 Katedra i Seminarium Filologii Germańskiej 1851-1939 (The Chair and Seminar of the German Studies in the years 1891-1938).

77 M. Stinia, Uniwersytet Jagielloński w latach 1871-1914, p. 206.

78 AUJ, WF II 157 Katedra i Seminarium Filologii Germańskiej 1851-1939 (The Chair and Seminar of the German Studies in the years 1891-1938).

79 AUJ, S II 619 Wukadinović Spirydion. 
his students as a temporary head of the department and curator of the Association of Germanists. A lecture in history of literature in the academic year 1932/1933 on Gerhard Hauptmann, at the motion of Dyboski, was conducted by a junior lecturer of German, doctor M. Unger. Such was the situation until Adam Kleczkowski assumed the lectures. ${ }^{80}$

Władysław Szafer, who was Dean of the Faculty of Philosophy in 1932, in a long letter to the ministry explained why the German specialist from Poznan was the best candidate for the vacant chair in Cracow. ${ }^{81}$ Eventually, almost a year later, President Mościcki appointed Kleczkowski full professor at the Jagiellonian University starting from 25 September 1933. In Poznań he was released from his duties on 21 October and two days later he appeared in the Dean's Office of the Department of Philosophy of the Jagiellonian University in order to assume his new duties. ${ }^{82}$

The attitude of the new head of the German studies department was more similar to his predecessor's than to Dyboski's. Kleczkowski was mostly busy with academic research, only occasionally going abroad with his lectures. ${ }^{83}$ His extensive and diverse work has often been discussed in relevant literature, which results from the fact that he was one of the best Polish Germanists. ${ }^{84}$ It is worth emphasizing Kleczkowski's enormous involvement in the work of the Polish Academy of Learning and above all for the development of the Cracow German studies, in which he was assisted by Doctor B. Rosenthalowa and after her resignation, in the years 1937/19381938/1939 - by Józef Kapica. In the last academic year before the outbreak of the war a voluntary junior lecturer in the department was Kazimiera Szylar, a high school teacher. A junior lecturer in German in the years 1934/1935-1938/1939 was Charlotte Hübner and the second one - Kapica. ${ }^{85}$ The years of undisturbed work and the time of détente between Poland and Germany until January 1939 allowed Kleczkowski to successfully continue the traditions of his predecessors, thanks to which the German studies department in Cracow was the best among the contemporary German studies departments at all Polish universities.

80 AUJ, WF II 157 Katedra i Seminarium Filologii Germańskiej 1851-1939 (The Chair and Seminar of the German Studies); WF II 192 Lektorat języka niemieckiego w latach 1851-1938 (German language classes in the years 1851-1938); AUJ, O 74/I Koło Germanistów (The Association of Germanists).

${ }^{81}$ AUJ, S II 619 Kleczkowski Adam. Szafer largely repeated, often in extenso, Dyboski's words as the commentator of the judging panel for the post of German studies professor (see Dyboski's letter AUJ, WF II 157 Katedra i Seminarium Filologii Germańskiej 1851-1939 (The Chair and Seminar of the German Studies).

82 AUJ, S II 619 Kleczkowski Adam.

83 Ibidem.

${ }^{84}$ See e.g.: O. Dobijanka-Witczakowa, op. cit., pp. 359-362; A. Kleczkowski, op. cit., pp. 11-14, 25-26; M. Kłańska, Marian Adam Kleczkowski (1883-1949) [in:] Uniwersytet Jagielloński..., pp. 292-300.

${ }_{85}$ AUJ, WF II 157 Katedra i Seminarium Filologii Germańskiej 1851-1939 (The Chair and Seminar of the German Studies); WF II 192 Lektorat języka niemieckiego w latach 1851-1938 (German language classes 1851-1938); U. Perkowska, op. cit., pp. 127, 149, 380. 


\section{CONCLUSION}

The challenges of the interwar period forced Polish scholars to redefine their roles and take up new tasks. This does not mean that non-university activity and community work did not exist before $1918^{86}$ - before scholars did not focus only on research and teaching either. Still, the creation of Polish state and the need for specialists in various fields of public life required intensifying the actions and in a way submitting some of them to the service for the state. Whereas the work in favor of the Polish nation was the legacy of the partition era, the years of the Great War joined the careers of some scholars with propaganda so strongly that in social reception the university professor who had not taken part in the publicum, did not meet the public expectations. ${ }^{87}$

Of course not only the German and English scholars from the Jagiellonian University proved that in the period under discussion the ideal of a scholar was understood as dynamic and versatile. ${ }^{88}$ That also concerned the Romanists or e.g. Wacław Lednicki, the only professor of Russian literature of the time, who in the 1930s apart from lecturing in Cracow, worked at the University in Brussels for three months every year. One should remember, however, that the "marriage" of scholars with the authorities and the latter's interest in the research of the former had their price. The growing expectations and public sympathies could change unexpectedly and the lack of support inside the scholarly circles as well as frequent friction and aversions might lead to rapid staff changes, like in the case of S. Wukadinović. There were various additional factors in such a small milieu as the employees of the Faculty of Philosophy of the Jagiellonian University, as well as considerable state interference in academic affairs. Due to all that it was not always academic achievements that were taken into account while evaluating particular scholars, neither was pedagogical success or developing intellectual potential of the faculty considered while selecting employees. What is more, even renowned scholars, like R. Dyboski, S. Wukadinović and A. Kleczkowski could happen to behave unethically and opportunistically and their career might not depend on their real credit.

86 On educational activity of the Jagiellonian University professors outside university see M. Stinia, Uniwersytet Jagielloński w latach 1871-1914, pp. 271-310.

87 M. Górny, Wielka Wojna profesorów. Nauki o człowieku (1912-1923), Warsaw 2014.

88 In this short text I omitted examples of various forms of activity of university teachers from both departments, but in fact their lectures, their involvement in the press and the radio and participation in the work of many non-academic organizations were enormous and worth remembering - see e.g.: K. Zwiercan-Borucka, Popularyzacja radiofonii w publikacjach pracowników naukowych Uniwersytetu Jagiellońskiego na łamach „IKC” $i$, Czasu” $w$ dwudziestoleciu międzywojennym (w 85. rocznice narodzin polskiej radiofonii) [in:] Virtuti et ingenio. Ksiegga Pamiatkowa dedykowana profesorowi Julianowi Dybcowi, ed. A.K. B anach, Kraków 2013, pp. 641-652. 


\section{BIBLIOGRAPHY}

\section{Archive sources}

Archiwum Akt Nowych w Warszawie (The Archive of New Files)

Fond. 503 Ambasada RP w Londynie, sign. 813 Wymiana profesorów między Polską a Wielką Brytanią.

Fond. 490 Ambasada RP w Waszyngtonie, sign. 1403-1410 (obchody Pułaskiego, 19281931).

Archiwum Nauki PAN i PAU w Krakowie (Archive of Science of Polish Academy of Sciences (PAN) and Polish Academy of Arts and Sciences (PAU) in Cracow)

Spuścizna Romana Dyboskiego, sygn. K III-90 (w opracowaniu).

Archiwum Uniwersytetu Jagiellońskiego w Krakowie (The Archives of the Jagiellonian University in Krakow)

O 74/I Koło Germanistów.

S II 619 Kleczkowski Adam; S II 619 Wukadinović Spirydion.

WF II 49 Protokoły Wydziału Filozoficznego za lata 1925-1939; WF II 88 Zasiłki rządowe na studia w kraju i zagranicą, ulgowe paszporty 1918-1939; WF II $157 \mathrm{Ka}$ tedra i Seminarium Filologii Germańskiej 1851-1939, WF II 192 Lektorat języka niemieckiego w latach 1851-1938; WF 529 Programy studiów uczelni zagranicznych i kursów organizowanych przez UJ dla cudzoziemców 1894-1939, WF II 530 Zawiadomienia o wycieczkach krajowych i zagranicznych z lat 1928-1939; WF II 534 Uroczystości i jubileusze uniwersyteckie.

Biblioteka Polskiej Akademii Umiejętności w Krakowie (The Library of the Polish Academy of Learning in Cracow)

The Manuscripts Catalogue, sign. 6463 Korespondencja Adama Kleczkowskiego z lat 1906-1949; sign. 6468 Materiały z lat 1926-1932 dotyczące sporu Spirydiona Wukadinovicia z Adamem Kleczkowskim; sign. 6491 Różne notatki Adama Kleczkowskiego i kopie listów do różnych z lat 1919-1949.

The Kosciuszko Foundation Archives, New York, USA

S. Mizwa's Archives, KF VI.40 Dyboski Roman; KF VI.41 Roman Dyboski. Publicity. 1928-1933; KF VI.42 Dyboski Roman, prof. Lectures in USA; KF XI.1 Correspondence. Oskar Halecki, 1937-1939; Photo Collection.

Державний Архів Львівської області м. Львів (State Archives of Lviv Region)

Fond 26 Uniwersytet Lwowski, op. 15, case 1546 Postel Paweł, case 771 Irvine Charles.

Fond 1262 Gimnazja obwodu lwowskiego, opis 58 Gimnazjum im. A. Mickiewicza w Samborze, sprawa 196. 


\section{Printed sources}

Sprawozdanie dwudzieste szóste dyrekcji c.k. Gimnazjum III w Krakowie za r. szk. 1909, Kraków 1909.

Sprawozdanie dwudzieste siódme dyrekcji c.k. Gimnazjum III w Krakowie za r. szk. 1910, Kraków 1910.

Sprawozdanie dwudzieste ósme dyrekcji c.k. Gimnazjum III w Krakowie za r. szk. 1911, Kraków 1911.

Sprawozdanie Dyrekcji I Wyższej Szkoły Realnej we Lwowie za rok szkolny 1909/1910, Lwów 1910.

Sprawozdanie Dyrekcji I Wyższej Szkoty Realnej we Lwowie za rok szkolny 1912/1913, Lwów 1913.

Sprawozdanie Dyrekcji c.k. Gimnazjum im. Arcyksiężniczki Elżbiety w Samborze za rok 1907, Sambor 1907.

Sprawozdanie Dyrekcji c.k. Gimnazjum im. Arcyksiężniczki Elżbiety w Samborze za rok 1908, Sambor 1908.

Sprawozdanie Dyrekcji c.k. Gimnazjum im. Arcyksiężniczki Elżbiety w Samborze za rok 1912, Sambor 1912.

Sprawozdanie Dyrekcji Gimnazjum VII we Lwowie za rok szkolny 1912/1913, Lwów 1913.

Sprawozdanie Dyrekcji Gimnazjum VIII we Lwowie za rok szkolny 1912/1913, Lwów 1913.

\section{The press}

"Czas" 1930, 1932

"Nowy Świat" 1930

"Poland" 1924-1930

"Prager Presse" 1929

"Ruch Literacki" 1930

\section{Memoirs}

Wysocki A., Tajemnice dyplomatycznego sejfu, $2^{\text {nd }}$ edition, Warszawa 1979.

\section{Other sources}

Bela T., Roman Dyboski (1883-1945) [in:] Uniwersytet Jagielloński. Złota Księga Wydziału Filologicznego, eds. J. Michalik, W. Walecki, Kraków 2000, pp. 286-288.

Chrostek M., Złote lata polonistyki lwowskiej (1919-1939), Rzeszów 2016.

Cieśla M., Dzieje nauk języków obcych w zarysie. Monografia z zakresu historii kultury, Warszawa 1974. 
Cieśla M., Spirydion Wukadinović profesor germanistyki na Uniwersytecie Jagiellońskim (1870-1938). Wspomnienie o nim [in:] Z dziejów germanistyki historycznoliterackiej w Polsce. Studia i materiały, ed. K.A. Kuczyński, Łódź 1991.

Dobijanka-Witczakow a O., Historia katedry germanistyki w Uniwersytecie Jagiellońskim [in:] Wydział Filologiczny Uniwersytetu Jagiellońskiego. Historia katedr, eds. W. Taszycki, A. Zaręba, Kraków 1964.

Drewniak B., Polsko-niemieckie zbliżenia w kregu kultury 1919-1939, Gdańsk 2005.

Dybiec J., Uniwersytet Jagielloński 1918-1939, Kraków 2000.

Frank A.F., Oil Empire: Visions of Prosperity in Austrian Galicia, Cambridge, MA-London 2007.

Górny M., Wielka Wojna profesorów. Nauki o człowieku (1912-1923), Warszawa 2014.

Kleczkowski A., Germanistyka, anglistyka i skandynawistyka w Polsce, Kraków 1948.

Kłańska M., Marian Adam Kleczkowski (1883-1949) [in:] Uniwersytet Jagielloński. Złota Księga Wydziału Filologicznego, eds. J. Michalik, W. Walecki, Kraków 2000, pp. 292 300.

Kłańska M., Spiridion Wukadinović (1870-1938) [in:] Germanistik in Polen. Zur Fachgeschichte einer literaturwissenschaftlichen Auslandsgermanistik-18 Porträts, eds. W. Kunicki, M. Zybura, Osnabrück 2011.

Kłańska M., Spiridion Wukadinović (1870-1938) [in:] Uniwersytet Jagielloński. Złota Księga Wydziału Filologicznego, eds. J. Michalik, W. Walecki, Kraków 2000, pp. 216-222.

Krajewska Z., Roman Dyboski (1883-1945), Katowice 1968.

Kuczyński K.A., Zygmunt Łempicki i polska germanistyka okresu międzywojennego [in:] $Z$ dziejów germanistyki historycznoliterackiej w Polsce. Studia i materiały, ed. K.A. Kuczyński, Łódź 1991.

Laskowska M., Tarnawski W., Dyboski Roman [in:] Polski słownik biograficzny, Kraków 1946, pp. 33-35.

Łempicki Z., Filologia germańska, jej zadania i potrzeby w Polsce, "Nauka Polska. Jej Potrzeby, Organizacja i Rozwój” 1929, vol. 10, pp. 336-346.

Majewski P.M., Społeczność akademicka 1915-1939 [in:] Dzieje Uniwersytetu Warszawskiego 1915-1945, Warszawa 1945, pp. 51-324.

Perkowska U., Corpus Academicorum Facultatis Philosophiae Universitatis Iagellonicae 1950-1945, Kraków 2007.

Petersen, Julius [in:] Internationales Germanistenlexikon 1800-1950, ed. Ch. König de Gruyter, Berlin 2003, pp. 1385-1388.

Podhajecka M., A History of Polish-English/English-Polish Bilingual Lexicography (1788-1947), Opole 2016.

Professor Roman Dyboski: Founder of English Studies in Poland. Proceedings of the Commemorative Conference for Roman Dyboski (1883-1945), Kraków, 1-2 June 1995, eds. T. Bela, E. Mańczak-Wohlfeld, Kraków 1997.

Pudłocki T., Ambasadorzy idei. Wkład intelektualistów w promowanie pozytywnego wizerunku Polski w Wielkiej Brytanii w latach 1918-1939, Kraków 2015.

Pudłocki T., Idea uniwersytetu wedtug Romana Dyboskiego, "Rocznik Komisji Nauk Pedagogicznych" 2016, vol. 69, pp. 155-173.

Pudłocki T., James MacCracken as a Lecturer at the Jagiellonian University (1946-1948) [in print].

Pudłocki T., Pierwsze stypendystki Fundacji Kościuszkowskiej z Polski w Stanach Zjednoczonych Ameryki (1925-1939) [in:] Człowiek - społeczeństwo - źródło. Studia ofiaro- 
wane Profesor Jadwidze Hoff, eds. Sz. Kozak, D. Opaliński, J. Polaczek, Sz. Wieczorek, W. Zawitkowska, Rzeszów 2014, pp. 119-133.

Pudłocki T., Uczeni przeciw , milczacej otchłani”. Współpraca Moniki M. Gardner i Romana Dyboskiego na rzecz sprawy polskiej w Wielkiej Brytanii, "Zeszyty Naukowe Uniwersytetu Jagiellońskiego. Prace Historyczne” 2014, 141/1, pp. 101-122.

Pudłocki T., Władysław Tarnawski. Cz. II. Przemyśl, lata przełomu, "Rocznik Przemyski" 2002, vol. 38, issue 1: Literatura i Język, pp. 67-78.

Pudłocki T., Władysław Tarnawski. Cz. III. Przemyślanin w drodze do katedry uniwersyteckiej, "Rocznik Przemyski” 2004, vol. 40, issue 3: Literatura i Język, pp. 71-92.

Sroka Ł.T., Wydziat Humanistyczny [in:] Academia militans. Uniwersytet Jana Kazimierza we Lwowie, ed. A. Redzik, Kraków 2015, pp. 597-598.

Stinia M., Państwowe szkolnictwo gimnazjalne $w$ Krakowie $w$ okresie autonomii galicyjskiej, Kraków 2004.

Stinia M., Uniwersytet Jagielloński w latach 1871-1914. Modernizacja procesu nauczania, Kraków 2014.

Tarnawski W., Uwagi o potrzebach anglistyki w Polsce, "Nauka Polska. Jej Potrzeby, Organizacja i Rozwój” 1929, vol. 10, pp. 347-349.

Wnęk J., Polskie przekłady literatury zagranicznej 1918-1939, Kraków 2006.

Zwiercan-Borucka K., Popularyzacja radiofonii $w$ publikacjach pracowników naukowych Uniwersytetu Jagiellońskiego na łamach ,IKC” $i$, Czasu” w dwudziestoleciu międzywojennym (w 85. rocznicę narodzin polskiej radiofonii) [in:] Virtuti et ingenio. Księga Pamiątkowa dedykowana profesorowi Julianowi Dybcowi, ed. A.K. Banach, Kraków 2013, pp. 641-652.

Żygulski Z., Germanistyka [in:] Historia nauki polskiej, ed. B. Suchodolski, vol. 4: 1863-1918, part 3, Wrocław-Warszawa-Kraków 1987, pp. 761-771. 